\title{
Effect of recycled tire polymer fibers on autogenous deformation of
}

\section{self-compacting concrete}

\author{
Martina Grubor $^{1 *}$, Nina Štirmer ${ }^{1}$, Marija Jelčić Rukavina ${ }^{1}$, Ana Baričević ${ }^{1}$ \\ ${ }^{1}$ Department of materials, University of Zagreb, Faculty of Civil Engineering, Zagreb, Croatia
}

Received: 20 June 2020 / Accepted: 02 September 2020 / Published online: 15 September 2020

(c) The Author(s) 2020. This article is published with open access and licensed under a Creative Commons Attribution 4.0 International License.

\begin{abstract}
Self-compacting concrete requires a special composition with an increased proportion of fine particles and larger volumes of paste compared to traditional vibrated concrete. Larger volumes of paste increase autogenous deformation, which can cause microcracking of concrete. The aim of this paper is to research the possibility of using recycled polymer fibers obtained from end-of-life tires to prevent micro cracking due to autogenous deformation in selfcompacting concrete. Mixes of self-compacting concrete containing 1 and $2 \mathrm{~kg} / \mathrm{m}^{3}$ of recycled tire polymer fibers and reference mixes were prepared and tested. Beside autogenous deformation, fresh state properties as well as compressive strength at the age of 3,7 and 28 days were tested. The results of the performed laboratory tests indicate that the use of recycled tire polymer fibers is effective for the reduction of autogenous deformation at early age with insignificant difference in compressive strength at tested ages.
\end{abstract}

Keywords: Self-compacting concrete; Autogenous deformation; Recycled tire polymer fibers

\section{Introduction}

Self-compacting concrete (SCC) requires a special composition with an increased proportion of fine particles and larger volumes of paste compared to traditional vibrated concrete [1,2]. Increased amount of fines and binder content is the main driving force for the large autogenous shrinkage [3], which can cause microcracking of early age concrete. This cracking negates the numerous advantages of SCC and thus considerably limits their prospective utilization in construction. Hence, the mechanisms and the mitigation strategies for autogenous shrinkage is the subject of research interest related to SCC. One of well-known mitigation strategies is using polypropylene fibers (PP) which reduces the occurrence of cracks during shrinkage in the early age of concrete by increasing strength and strain capacity of cement composites [4-7]. Since the dimensions and composition of recycled polymer tire fibers (RTPF) obtained from waste tire recycling are similar to dimensions of PP fibers, during FP7 Anagennisi project [8], a concept involving replacement of industrial fibers with fibers obtained by waste tire recycling has been developed. RTPF are high-quality polymer fibers which were used mostly for energy purposes as fuel in the cement industry or disposed at landfills (Fig. 1a and Fig. 1b). Due to the high flammability and low density, this material represents a major challenge for the storage. It is estimated that 250000 tons of this waste are generated annually only in the European Union [8].

The aim of this preliminary research is to investigate the possibility of using RTPF to decrease autogenous deformations of self-compacting concrete. For that purpose, experimental study was conducted on concrete mixes with 1 and $2 \mathrm{~kg} / \mathrm{m}^{3}$ RTPF where fresh properties (slump flow, slump flow time, L-box, segregation resistance, density, air content), autogenous deformation and compressive strength were tested and analysed. Obtained results were compared with those obtained for mix without fibers and for mix with 1 $\mathrm{kg} / \mathrm{m}^{3}$ of monofilament PP fibers serving as reference mixes.

* Corresponding author: Martina Grubor, Email: $\underline{\text { martina.grubor@grad.unizg.hr }}$ 


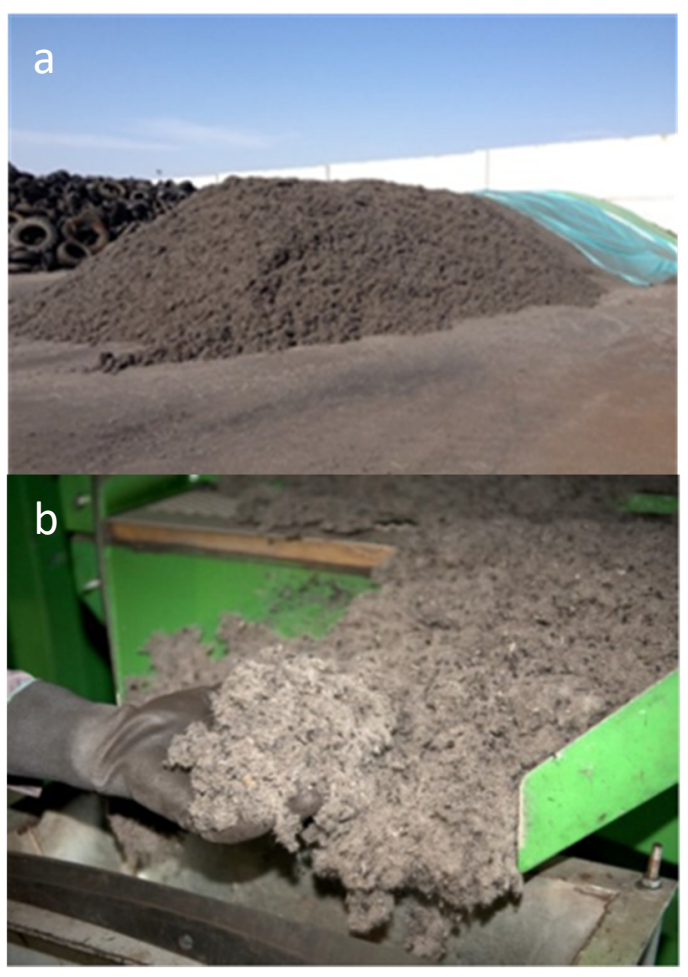

Figure 1. Recycled tire polymer fibers: a) Landfill of RTPF; b) RTPF in the process of transport to landfill.

\section{Experimental program \\ 2.1 Materials}

All SCC mixes were prepared with CEM II/B-M (S, V) $42.5 \mathrm{~N}$, crushed limestone as aggregate $(0 / 4 \mathrm{~mm}, 4 / 8 \mathrm{~mm}$ and 8/16 $\mathrm{mm}$ ), limestone filler, superplasticiser (polycarboxylic ether hyperplasticiser) and viscosity modified agent. Following, maximum aggregate size was selected to be $16 \mathrm{~mm}$ and reference grading curve according Fuller's equation was used $[9,10]$. Fig. 2 shows the grading curves for aggregates used in all SCC mixes.

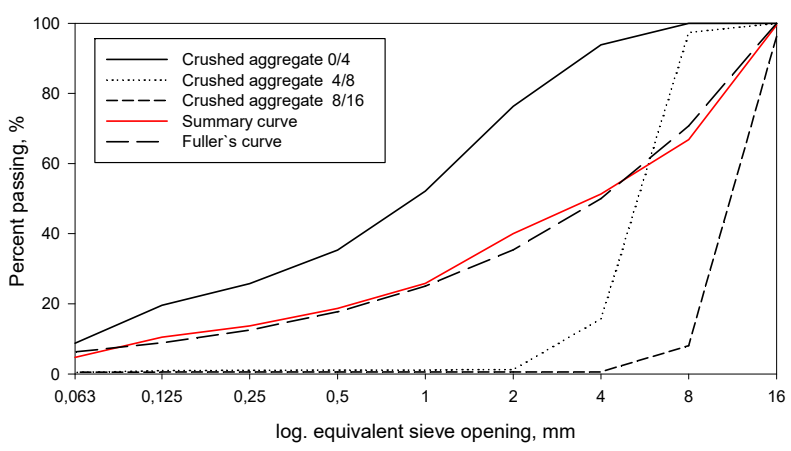

Figure 2. Aggregate grading curves.

Two types of fibers were used as reinforcement: monofilament polypropylene (PPm) fibers and cleaned recycled tire polymer fibers (RTPFc) (Fig. 3a and Fig. 3b). Monofilament micro PP fibers in the dosage of $1 \mathrm{~kg} / \mathrm{m}^{3}$ were used in the reference mix. Properties of used PPm fibers are presented in Table 1. RTPF were obtained from a Croatian tire recycling company - Gumiimpex GRP. After process of mechanical tire

recycling, $80 \%$ of rubber granules, $15 \%$ of recycled steel fibers and $5 \%$ of recycled polymer fibers with firmly adhered rubber particles were obtained. RTPF are usually heavily contaminated with residual rubber (Fig. 1b) which can negatively affect mechanical concrete properties. To solve this problem, innovative cleaning device was developed within Anagennisi project to remove residual rubber from RTPF [11] and to obtain cleaned RTPF.

Three polymers were detected as constituent of analysed RTPF fibres: polyesters poly(ethylene terephthalate) PET, poly(butylene terephthalate) PBT and polyamide 66 PA [11]. Properties of cleaned RTPF (RTPFC) are presented in Table 1. Microscopic examination was performed to determine the average diameter of the RTPFc. Three different types of fibers were found with average diameters of 12,20 , and $30 \mu \mathrm{m}$ (Table 1). Length distribution analysis of fibers showed that $80 \%$ of the RTPFC are shorter than $13 \mathrm{~mm}$ (Fig. 4).

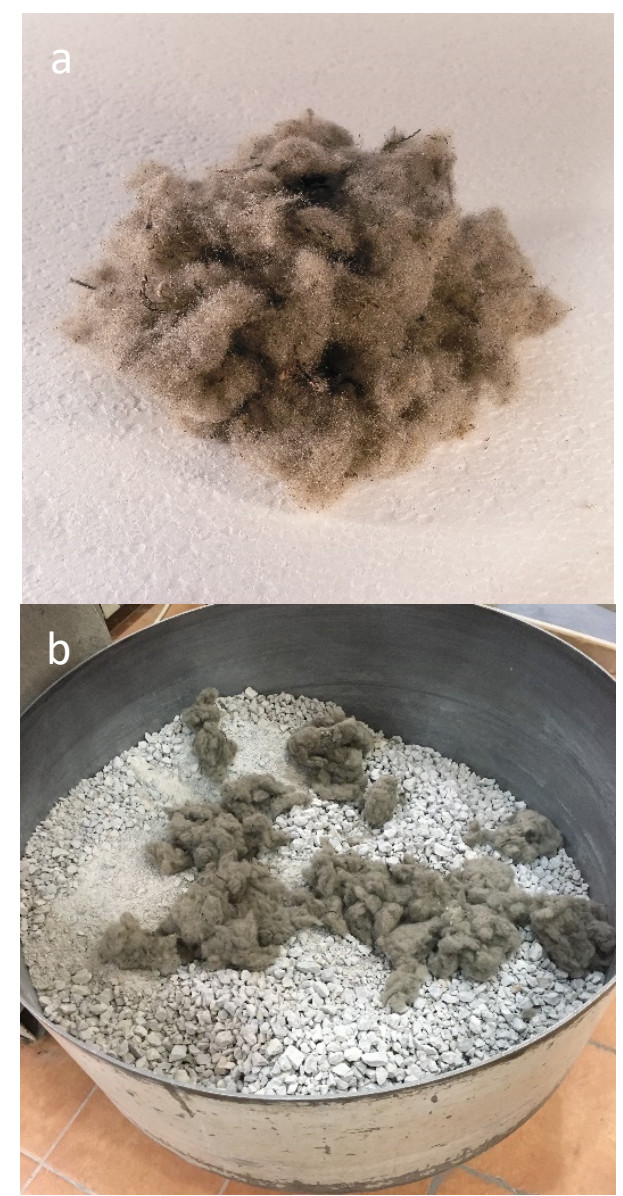

Figure 3. Cleaned recycled tire polymer fibers (RTPFc): a) picture of RTPFc; b) RTPFc with aggregates and filler. 
Table 1. Properties of fibers [11-13].

\begin{tabular}{|c|c|c|c|c|c|}
\hline Type of fibers & Length, mm & \multicolumn{2}{|c|}{ Diameter, $\mu \mathrm{m}$} & Density, $\mathrm{g} / \mathrm{cm}^{3}$ & Composition \\
\hline $\begin{array}{l}\text { Monofilament polypropylene } \\
\text { fibers (PPm) }\end{array}$ & 6 & \multicolumn{2}{|c|}{ approx. $32 \mu \mathrm{m}$} & 0.91 & $100 \%$ PP \\
\hline \multirow{3}{*}{$\begin{array}{l}\text { Cleaned recycled tire polymer } \\
\text { fibers (RTPFc) }\end{array}$} & \multirow{3}{*}{$9.5 \pm 4.6$} & type 1 & $30.1 \pm 2.0$ & \multirow{3}{*}{$1.32 *$} & \multirow{3}{*}{$\begin{array}{l}* * \text { Approx. } 60 \% \text { PET, } 25 \% \text { PA } \\
66 \text { and } 15 \% \text { of PBT. }\end{array}$} \\
\hline & & type 2 & $20.2 \pm 1.7$ & & \\
\hline & & type 3 & $12.4 \pm 1.8$ & & \\
\hline
\end{tabular}

*value determined using density from literature [13] and share of polymer type in composition of RTPFC

**PET - poly(ethylene-terephthalate), PA 66 - polyamide 66, PBT - poly(butylene-terephthalate).

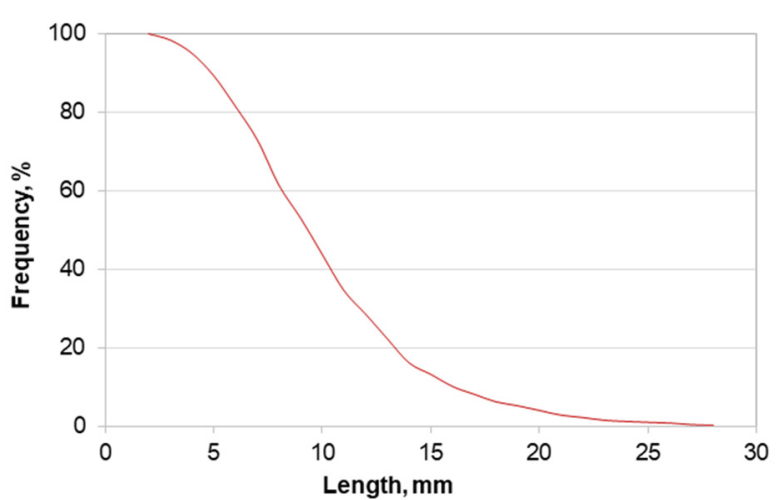

Figure 4. Length distribution of RTPFc [12].

\subsection{Mix design and preparation of specimens}

Concrete mix designs are presented in Table 2. Mixes were designed for target slump flows ranging from 660 to $750 \mathrm{~mm}$, which was achieved by using the superplasticiser based on polycarboxylic ether polymers. All mixes were designed according to CBI method developed in Sweden [14]. For all mixes, constant powder quantity was $670 \mathrm{~kg} / \mathrm{m}^{3}$, watercement ratio $(\mathrm{w} / \mathrm{c})$ was 0.54 and water-powder ratio $(\mathrm{w} / \mathrm{p})$ was 0.36 .

Table 2. Concrete mix design.

\begin{tabular}{|l|l|l|l|l|}
\hline Components $\left(\mathrm{kg} / \mathrm{m}^{3}\right)$ & SCC & $\begin{array}{l}\text { SCC- } \\
\text { PPm }\end{array}$ & $\begin{array}{l}\text { SCC- } \\
\text { 1RTPFc }\end{array}$ & $\begin{array}{l}\text { SCC- } \\
\text { 2RTPFc }\end{array}$ \\
\hline Cement & 450 & 450 & 450 & 450 \\
\hline Water & 243 & 243 & 243 & 243 \\
\hline Limestone filler & 220 & 220 & 220 & 220 \\
\hline Superplasticiser & 4.87 & 6.94 & 6.94 & 6.94 \\
\hline VMA & 0.2 & 0.2 & 0.2 & 0.2 \\
\hline w/c & 0.54 & 0.54 & 0.54 & 0.54 \\
\hline Fibres & -- & 1 & -- & - \\
\hline PPm & -- & -- & 1 & 2 \\
\hline RTPFc & & & & \\
\hline Aggregate & 842 & 839 & 839 & 840 \\
\hline $0 / 4$ & 187 & 187 & 186 & 186 \\
\hline $4 / 8$ & 421 & 420 & 418 & 419 \\
\hline $8 / 16$ &
\end{tabular}

All constituting materials were kept for at least 24 hours in the laboratory at a temperature of $20 \pm 2^{\circ} \mathrm{C}$ before mixing. The mixing procedure was as followed: first, the aggregates, filler and the RTPFc or PPm fibers were mixed 120 seconds to ensure a good dispersion of fibers. Mixing was then proceeded for 30 seconds after adding one third of the water quantity. After cement was added, the mixing was resumed for another 30 seconds. Second third of the water was added after addition of cement and mixing was proceeded for another 60 seconds. Finally, the remaining water, superplasticiser and VMA were added, and the mixing continued for another 90 seconds. The mixing was stopped for 120 seconds and finally continued for another 180 seconds.

\subsection{Test methods}

Testing of concrete properties in fresh and hardened state was performed according to the test methods listed in Table 3. As it can be seen from the table, all methods for testing concrete properties (for both fresh and hardened) were standardized except the method for autogenous deformation.

Table 3. Tests on self-compacting concrete [15-20].

\begin{tabular}{|l|l|}
\hline Property & Test method \\
\hline Density & EN 12350-6:2009 \\
\hline Air content -- Pressure method & EN 12350-7:2009 \\
\hline Slump flow & EN 12350-8:2010 \\
\hline Slump flow time $\left(\mathrm{t}_{500}\right)$ & EN 12350-8:2010 \\
\hline L-box test & EN 12350-10:2010 \\
\hline Segregation resistance & EN 12350-11:2010 \\
\hline Autogenous deformation & - \\
\hline Compressive strength & EN 12390-3:2009/AC:2011 \\
\hline
\end{tabular}

Autogenous deformation was measured on specimens using steel moulds with dimensions of $100 \times 100 \times 400 \mathrm{~mm}^{3}$. Fig. 5 shows a schematic presentation of the experimental set-up for measuring early age deformations.

For each mix, three specimens were prepared. At the sides of each mould, displacement transducers were attached, which are further connected to a computer. Linear displacement gauges with an accuracy of $0.001 \mathrm{~mm}$ were used. Information about displacement is logged automatically at 1 minute intervals. The length change of the test specimen was equal to the sum of displacements measured by the two digital indicators. The length of the measuring base for calculation of deformations was taken as the distance through the specimen between measuring pins which was $380 \mathrm{~mm}$. 


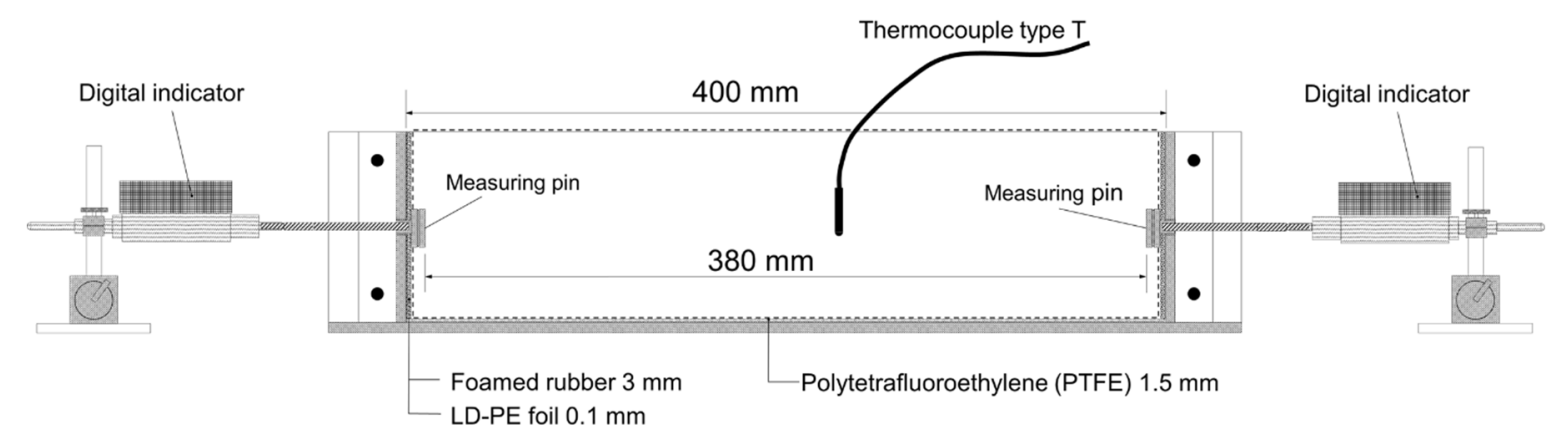

Figure 5. Experimental set-up for measuring autogenous deformation [11].

The end plates of each mould had holes bored in the centre for the insertion of deformation measurement pins. Linear displacement gauges are connected with one-side of measuring pins with two-component glue to enable accurate measurement of linear displacements. The other side of the measuring pin was embedded into the concrete after filling the mould in a way that it can freely move together with the specimen. Polytetrafluoroetylene sheet ( $1.5 \mathrm{~mm}$ thick) was placed at the bottom of the mould. A 3-mm thick foamed rubber insert was placed between sides of the mould and concrete specimen to allow length increase of the specimen due to possible swelling. Polyethylene foil was placed into mould; all the edges were sealed using silicone sealant. Area between measuring pin and polyethylene foil are joined by the thin layer of elastic putty to completely prevent drying and evaporation of moisture during the test time. After casting the concrete into the mould, the top side of concrete specimen was wrapped with polyethylene foil and sealed with two layers of adhesive tape.

Since autogenous deformation is, in general, affected by the thermal expansion and contraction caused by the temperature change in concrete due to hydration reaction, the temperature in the centre of the specimens was measured by thermocouples ( $T$ type). The thermocouples were connected to a digital data logger which was used to record the temperature change at set intervals of 1 minute. During measurement, all specimens were stored in a chamber at $19 \pm 2{ }^{\circ} \mathrm{C}$. Fig. 6 presents the whole set-up for autogenous deforrmation monitoring.

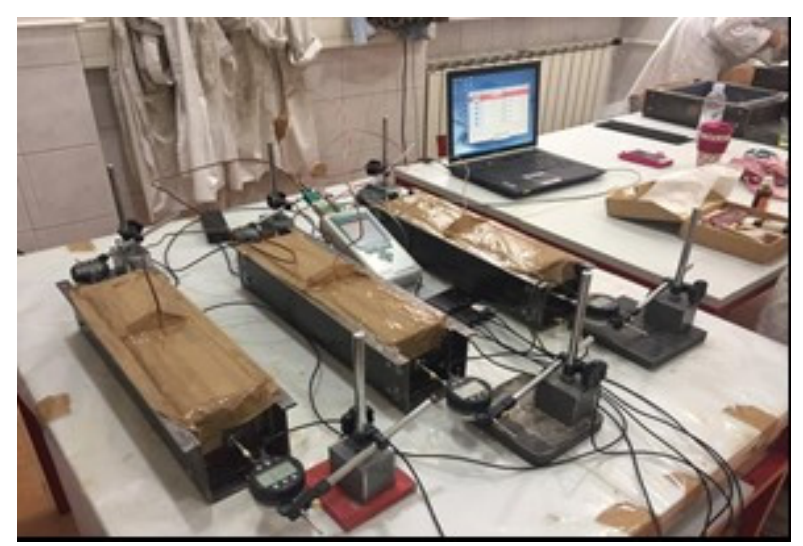

Figure 6. Testing autogenous deformations.
Fresh concrete properties (slump flow, slump flow time, Lbox, segregation resistance, density, air content) were obtained immediately after mixing. Testing of SCC properties are more extensive and demanding from testing traditional vibrated concrete in fresh state and it requires to meet special criteria. The filling ability and stability of self-compacting concrete in the fresh state can be defined by four key characteristics: flowability, viscosity, passing ability and segregation. In Table 4 the SCC criteria provided in EN 206-9 [21] and EFNARC recommendations [22] are presented.

Table 4. SCC criteria for testing fresh properties [21,22].

\begin{tabular}{|c|c|c|c|c|}
\hline Characteristic & $\begin{array}{l}\text { Preferred } \\
\text { test method }\end{array}$ & $\begin{array}{l}\text { Parameter } \\
\text { of testing }\end{array}$ & $\begin{array}{l}\text { Results } \\
\text { of } \\
\text { testing }\end{array}$ & Classes \\
\hline \multirow{3}{*}{ Flowabilitiy } & \multirow{3}{*}{$\begin{array}{l}\text { Slump flow } \\
\text { test }\end{array}$} & \multirow{3}{*}{$\mathrm{SF}, \mathrm{mm}$} & $\begin{array}{l}550- \\
650 \\
\mathrm{~mm}\end{array}$ & SF1 \\
\hline & & & $\begin{array}{l}660- \\
750 \\
\mathrm{~mm}\end{array}$ & SF2 \\
\hline & & & $\begin{array}{l}760- \\
850 \\
\mathrm{~mm} \\
\end{array}$ & SF3 \\
\hline \multirow{2}{*}{ Viscositiy } & \multirow{2}{*}{$\begin{array}{l}T_{500} \text { slump } \\
\text { flow test }\end{array}$} & \multirow{2}{*}{$t_{500, s}$} & $<2 \mathrm{~s}$ & VS1 \\
\hline & & & $\geq 2 \mathrm{~s}$ & VS2 \\
\hline \multirow{2}{*}{$\begin{array}{l}\text { Passing } \\
\text { ability }\end{array}$} & \multirow{2}{*}{$\mathrm{L}$ box test } & \multirow{2}{*}{$\mathrm{PL}=\mathrm{h}_{2} / \mathrm{h}_{1},-$} & $\begin{array}{l}\geq 0.8 \\
(2 \\
\text { bars })\end{array}$ & PL1 \\
\hline & & & $\begin{array}{l}\geq 0.8 \\
(3 \\
\text { bars })\end{array}$ & PL2 \\
\hline \multirow[b]{2}{*}{ Segregation } & \multirow{2}{*}{$\begin{array}{l}\text { Segregation } \\
\text { resistance } \\
\text { (sieve) test }\end{array}$} & \multirow[b]{2}{*}{$\mathrm{SR}, \%$} & $\leq 20 \%$ & SR1 \\
\hline & & & $\leq 15 \%$ & SR2 \\
\hline
\end{tabular}

Autogenous deformations were started to be monitored immediately after casting in moulds. For compressive strength testing, concrete was casted in cube moulds with dimensions $150 \times 150 \times 150 \mathrm{~mm}^{3}$. After casting, the specimens were kept covered in the laboratory conditions for 24 hours until demoulding, to prevent evaporation of water. After demoulding, the specimens were kept in the moist room at $20 \pm 2^{\circ} \mathrm{C}$ and $\mathrm{RH} \geq 95 \%$, until testing at the age of 3,7 and 28 days. 


\section{Results and discussion}

\subsection{Fresh concrete properties}

Comparing the obtained results with the SCC criteria provided in Table 4, it can be concluded that tested mixes exhibited satisfactory properties in fresh state and can be used for structural applications. Obtained results with related classes of SCC are shown in Table 5.

The obtained slump-flow values ranged from 660 (for SCC$\mathrm{PPm}$ ) to $735 \mathrm{~mm}$ (for reference mix, SCC), achieving the targeted range, SF2. Slump flow test for mix SCC showed that there is no segregation of aggregate at the edge of "cake" for all tested mixes. Figs. 7a and 7b present slump-flow test for SCC mix. Values of $t_{500}$ ranged from $0.56 \mathrm{~s}$ (for SCC-1RTPFC) to $1.06 \mathrm{~s}$ (SCC-PPm). A higher time value $t_{500}$ indicates a higher viscosity. Therefore, mix with $1 \mathrm{~kg} / \mathrm{m}^{3}$ of monofilament polypropylene fibers had the highest viscosity. However, no clear conclusion can be drawn about the effect of used fibers on workability properties (filling, passing ability and segregation resistance), mainly because of various superplasticiser dosages, which primarily affect these properties.

The density of the studied mixes ranged from $2.27 \mathrm{~kg} / \mathrm{m}^{3}$ (for the SCC-2RTPFC) to $2.29 \mathrm{~kg} / \mathrm{m}^{3}$ (for the SCC, SCC-PPm and SCC- 1RTPFC). The density decreased with the addition of RTPF in comparison with mix SCC. Also, density decreased with higher fiber dosages. However, the differences in density of observed mixes were less than $1 \%$, which indicates that RTPF did not have significant effect on concrete density in fresh state. The results of testing air content ranged from $0.9 \%$ (for SCC-1RTPFC) to $1.7 \%$ (for SCC-PPm). Generally, it can be observed that the air content was increased with increasing the fibre dosage, i.e. the addition of $2 \mathrm{~kg} / \mathrm{m}^{3}$ of RTPFc increased the air content for $77 \%$ compared to the mix with $1 \mathrm{~kg} / \mathrm{m}^{3}$ of RTPFC.

\subsection{Compressive strength}

Fig. 8 presents the results of the compressive test at the age of 3, 7 and 28 days. For each age, 3 specimens were tested, and the results are presented in terms of mean value and absolute deviation. After 3 days of curing, SCC mixes developed between $66.6 \%$ (for SCC-1RTPFC) and $71.2 \%$ (for $\mathrm{SCC}$ ) of their 28-day compressive strength, while after 7 days, development was between $79.2 \%$ (for SCC-1RTPFC) and $85.2 \%$ (for SCC-2RTPFC). After 28 days of curing, the lowest value of compressive strength was obtained for mix SCC-
2RTPFC, which was around $7 \%$ lower compared to reference $\operatorname{mix}(\mathrm{SCC})$.

The addition of fibers (PPm and RTPFC) in SCC mixes, did not affect the compressive strength significantly; the difference in the obtained values for each age were within a $10 \%$ variation.

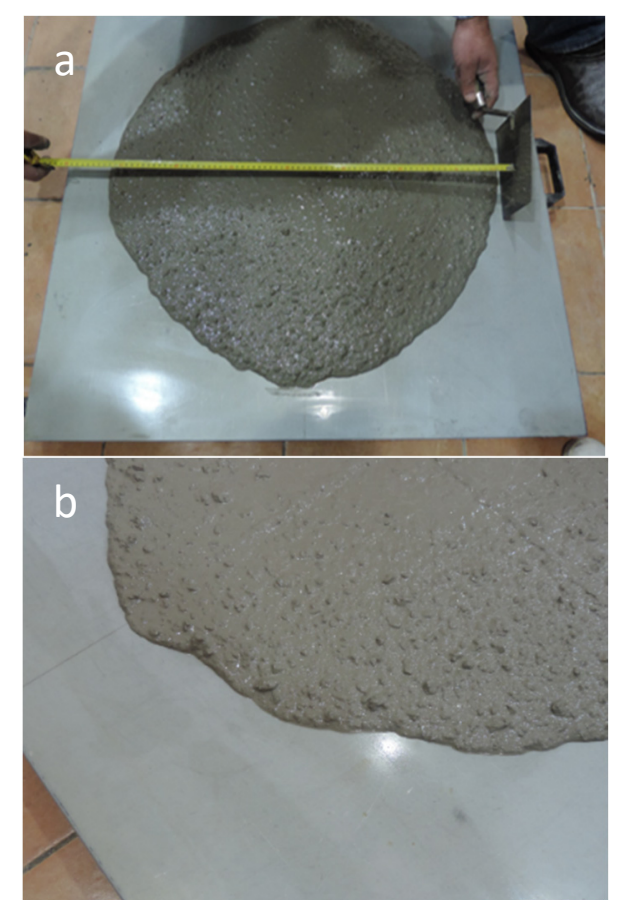

Figure 7. Slump flow test: a) Slump flow test for mix SCC, b) Edge of SCC mix during the slump flow test.

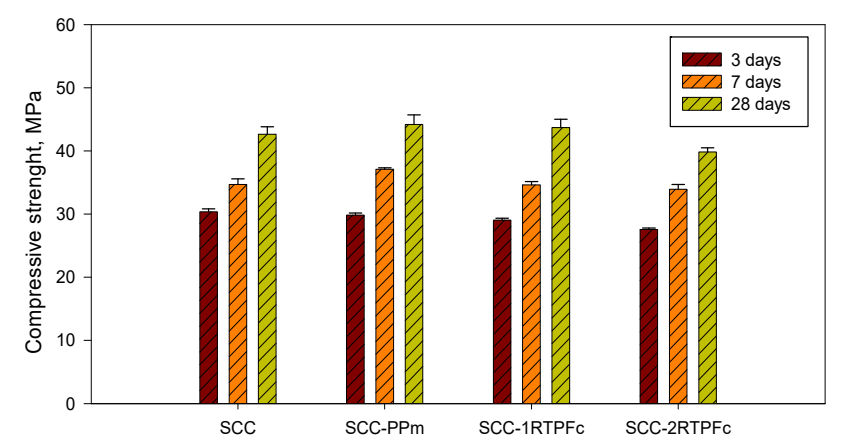

Figure 8. Compressive strength for SCC mixes after 3, 7 and 28 days.

Table 5. Results of testing fresh concrete properties.

\begin{tabular}{|c|c|c|c|c|c|c|c|c|c|c|}
\hline \multirow{2}{*}{ MIX ID } & \multirow{2}{*}{$\begin{array}{l}\text { Density, } \\
\mathrm{g} / \mathrm{cm}^{3}\end{array}$} & \multirow{2}{*}{$\begin{array}{l}\text { Air content, } \\
\%\end{array}$} & \multicolumn{2}{|c|}{$\begin{array}{l}\text { Slump flow, } \\
\mathrm{mm}\end{array}$} & \multicolumn{2}{|l|}{$\begin{array}{l}\mathrm{t}_{500}, \\
\mathrm{~s}\end{array}$} & \multicolumn{2}{|l|}{$\begin{array}{l}\text { L-box, } \\
3 \text { bars }\end{array}$} & \multicolumn{2}{|c|}{$\begin{array}{l}\text { Segregation } \\
\text { resistance, \% }\end{array}$} \\
\hline & & & Value & Class & Value & Class & Value & Class & Value & Class \\
\hline SCC & 2.29 & 1.00 & 735 & SF2 & 0.63 & VS1 & 0.80 & PL2 & 10.10 & SR2 \\
\hline SCC-PPm & 2.29 & 1.70 & 660 & SF2 & 1.06 & VS1 & 0.80 & PL2 & 7.95 & SR2 \\
\hline SCC-1RTPFC & 2.28 & 0.90 & 700 & SF2 & 0.56 & VS1 & 0.80 & PL2 & 8.42 & SR2 \\
\hline SCC-2RTPFC & 2.27 & 1.60 & 670 & SF2 & 0.72 & VS1 & 0.80 & PL2 & 7.09 & SR2 \\
\hline
\end{tabular}




\subsection{Autogenous deformations}

Fig. 9 shows the early age concrete deformations (for the first 24 hours). The deformations presented in the graph, are the sum of the autogenous and thermal deformations (3 specimens per mix). Apart from the deformation values, the graph also presents the temperature developed inside the specimen. In accordance to Tazawa et al. [23] start of the autogenous deformations can be taken as the time of cement setting which approximately coincides with the start of temperature rise in the specimens put in the environment with constant temperature. Therefore, "time zero" or start of autogenous deformation was determined from the moment when cooling of the concrete becomes influenced by the liberated heat of hydration.

Thermal deformations were not separated from autogenous deformation, because thermal coefficients of the studied mixes were not determined and their influence on total deformations is considered negligible after 24 hours. Namely, deformation caused by temperature increase is not taken into account because of the following:

- $\quad$ Initial temperature of all SCC mixes were $21.3 \pm 0.7^{\circ} \mathrm{C}$. Temperature in test room was $20 \pm 1.5^{\circ} \mathrm{C}$.

- At the beginning of the measurement, hydration in cement composites has not yet begun, so the graph (Figure 9) shows a decrease in the temperature of the concrete to the age of the test mixtures from 3.4 to 5.4 hours. The decrease in concrete temperature after the end of the induction period stops due to the beginning of heat release, this moment is called „time zero" or the moment when cooling of concrete becomes influenced by liberated heat. At the "time zero" temperature within specimens is between $20.8 \pm 0.3^{\circ} \mathrm{C}$.

- During the acceleration period, the maximum concrete temperature is reached, and it is between 14 and 16 hours from the beginning of the measurement and it was $24.9-25^{\circ} \mathrm{C}$. After $24 \mathrm{~h}$, ie. at the end of the test period, the temperature in the SCC mixes decreased to $21.6 \pm 0.2^{\circ} \mathrm{C}$. Based on the analysis of temperature differences during the measurement, it can be concluded that the temperature differences are small.

Therefore, deformations caused by the change in temperature are small, so it is assumed that the measured deformations at the end of the measurement period can be considered as autogenous deformation [24]. a

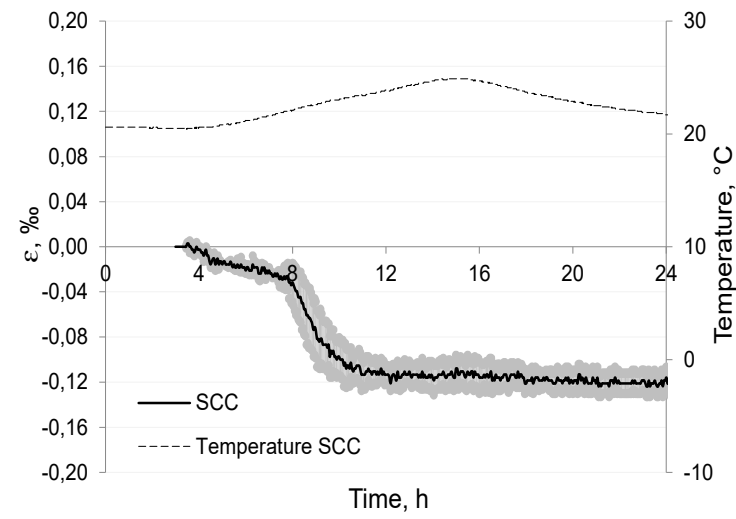

b

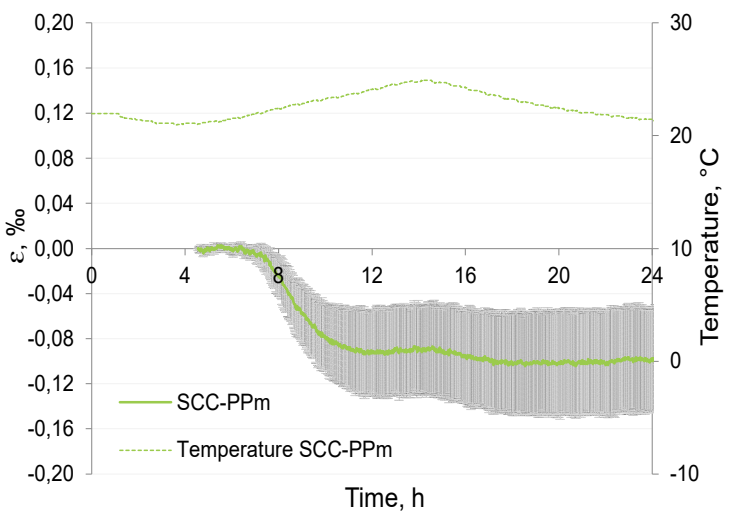

C

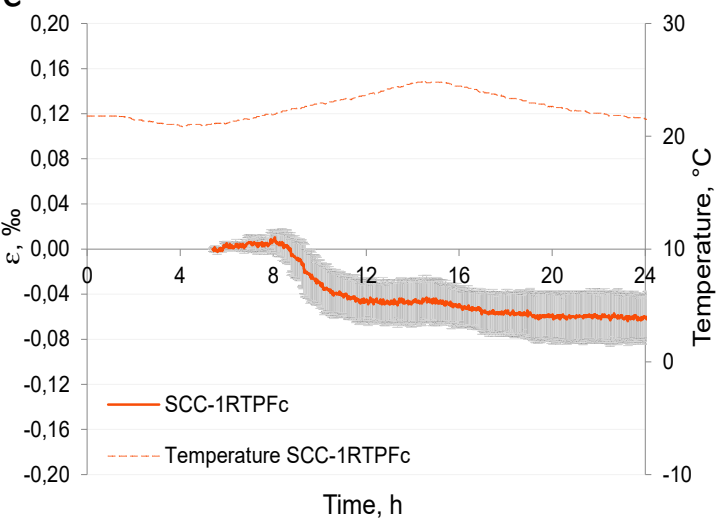

d

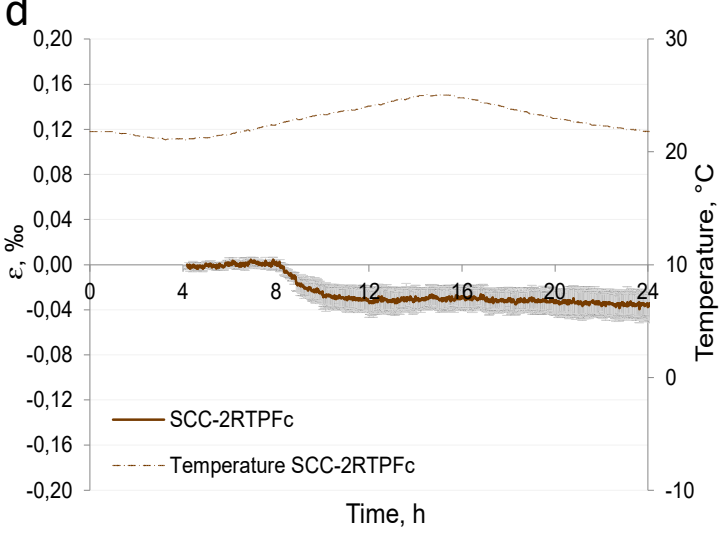

Figure 9. Average results of the early age deformation measurements: a) SCC; b) SCC-PPm; c) SCC-1RTPFc; d) SCC-2RTPFC. 
Results showed a positive contribution of all used fiber types; where additional improvement was achieved when RTPFC were used. At the end of the testing period (Fig. 10), autogenous deformation of mix without fibers (SCC) was $0.116 \%$, for mixes with $1 \mathrm{~kg} / \mathrm{m}^{3}$ of PP (SCC-PPm) it was $0.100 \%$ and for mixes with $1 \mathrm{~kg}$ (SCC-1RTPFC) and $2 \mathrm{~kg}$ (SCC2RTPFC) of RTPFc per $\mathrm{m}^{3}$ autogenous deformations were $0.061 \%$ and $0.038 \%$ respectively. By increasing the content of RTPFc, further improvement was achieved regarding the total autogenous deformation. The addition of $2 \mathrm{~kg}$ of RTPFc per $\mathrm{m}^{3}$ decreased autogenous deformation by more than 3fold compared to the mix without fibers (SCC).

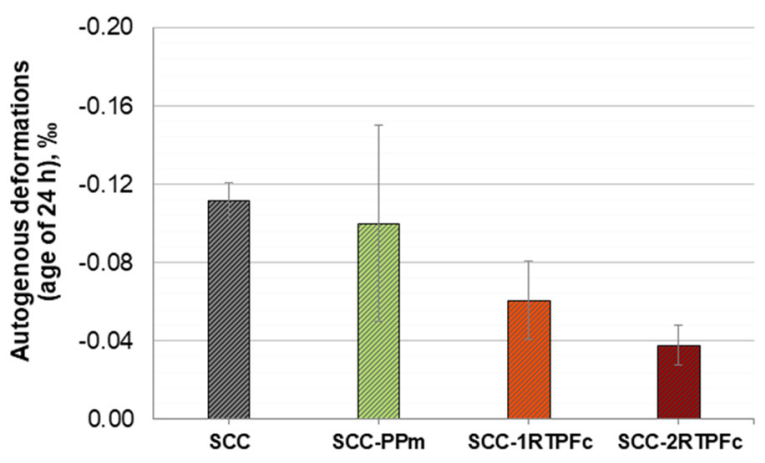

Figure 10. Autogenous deformations for SCC mixes at the end of the testing period (age of $24 \mathrm{~h}$ ).

The influence of RTPFc fibers on autogenous deformations can be explained by the fact that the modulus of elasticity of fibers is higher compared to the modulus of concrete during first 24 hours of hardening, which is why the presence of those fibers has positive influence on stress distribution and lower shrinkage stains. The obtained results are in accordance with the literature data for concrete with PP fibers $[4,5,25,26]$ but also with results obtained with ordinary and sprayed concrete with RTPF fibers $[11,27,28]$.

\section{Conclusions}

The influence of the RTPFc addition on the properties of selfcompacting concrete in fresh and hardened state was investigated. Besides typical fresh properties (slump flow, slump flow time, L-box, segregation resistance, density, air content), the experimental testing included autogenous deformations and compressive strength of four SCC mixes: mix without fibers, mix with $1 \mathrm{~kg} / \mathrm{m}^{3} \mathrm{PPm}$ fibers and two mixes with 1 and $2 \mathrm{~kg} / \mathrm{m}^{3}$ of RTPFc. Concerning workability properties, all studied mixes achieved satisfactory results required for self-compatibility (filling, passing ability and resistance to segregation). The differences in density of observed mixes were less than $1 \%$, which indicated that RTPFc did not have significant effect on concrete density in fresh state. The air content was increased with increasing the fiber dosage, i.e. the addition of $2 \mathrm{~kg} / \mathrm{m}^{3}$ of RTPFc increased the air content for $77 \%$ compared to the mix with $1 \mathrm{~kg} / \mathrm{m}^{3}$ of RTPFc. Compressive strength results showed that the addition of fibers (PPm and RTPFC) in SCC mixes, did not affect the compressive strength significantly at different tested ages (3, 7 and 28 days). The difference in the obtained values of all tested mixes for each age were within a $10 \%$ variation. The highest effect of fibers was shown on autogenous deformations. The addition of $2 \mathrm{~kg} / \mathrm{m}^{3}$ of RTPFc decreased the autogenous deformation by more than 3-fold compared to the mix without fibers (SCC). However, after 24 hours of testing, autogenous deformation of mix without fibers was $0.116 \%$, whilst for mixes with $1 \mathrm{~kg}$ of PPm, $1 \mathrm{~kg}$ and $2 \mathrm{~kg}$ of RTPFc per $\mathrm{m}^{3}$ deformations were $0.100 \%$, $0.061 \%$ and $0.038 \%$, respectively.

The results of the performed laboratory tests indicate that RTPFc can be used as substitute for PPm fibers, since they do not impair the workability properties of SCC concrete and at the same time assure the reduction of autogenous deformation at early age with insignificant influence on compressive strength. Usage of RTPFC in SCC represents a potential for preventing microcracks in young concrete caused by autogenous deformation which is the basis for the development of more durable structures and at the same time preventing current practice of landfilling this material.

\section{Acknowledgements}

The research presented in this paper is conducted within the project "Anagennisi - Innovative Reuse of all Tyre Components in Concrete" (Contract agreement number: 603722) funded by the European Commission under the $7^{\text {th }}$ Framework Programme Environment topic. Authors would like to thank GUMIIMPEX for their support and students Matea Dzaja, Marija Held and Petra Ruzic for their contribution during experimental work. The work of Martina Grubor was supported by Croatian Science Foundation in the framework of the programme "Young Researchers' Career Development Project - Training of New Doctoral Students".

\section{References}

[1] E. Rozière, S. Granger, P. Turcry, A. Loukili, Influence of paste volume on shrinkage cracking and fracture properties of self-compacting concrete. Cem Concr Compos (2007) 29(8): 626-36. https://doi.org/10.1016/j.cemconcomp.2007.03.010

[2] B. Craeye, G. De Schutter, B. Desmet, J. Vantomme, G. Heirman, L. Vandewalle, O. Cizer, S. Aggoun, E.H. Kadri, Effect of mineral filler type on autogenous shrinkage of self-compacting concrete. Cem Concr Res (2010) 40(6): 908-13. https://doi.org/10.1016/j.cemconres.2010.01.014

[3] D. Bjegovic, N. Stirmer, Theory and technology of concrete, University of Zagreb, Faculty of civil engineering, 2015.

[4] D. Saje, B. Bandelj, J. Sustersic, J. Lopatic, F. Saje, Shrinkage of Polypropylene Fiber-Reinforced High-Performance Concrete. J Mater Civ Eng (2011) 23(7): 941-52. https://doi.org/10.1061/(ASCE)MT.1943-5533.0000258

[5] D. Saje., B. Bandelj, J. Sustesic, J. Lopatic, F. Saje, Autogenous and Drying Shrinkage of Fibre Reinforced High-Performance Concrete. J Adv Conc Technol (2012) 10(2): 59-73. https://doi.org/10.3151/jact.10.59

[6] D. Saje, Reduction of the Early Autogenous Shrinkage of High Strength Concrete. Adv Mater Sci Eng (2015) 2015: 310641. https://doi.org/10.1155/2015/310641

[7] XB. He, Y. Li, Q. Shen, Impermeability Durability of SCC Reinforced with Fibrillated Polypropylene Fiber. Open Civ Eng J (2015) 9(1): 15966. https://doi.org/10.2174/1874149501509010159

[8] Project Anagennisi - Innovative Reuse of All Tyre Components in Concrete, https://cordis.europa.eu/docs/results/603/603722/final1final-report-v1-7.pdf, last accessed 2020/1/14

[9] W.B. Fuller, S.E. Thompson, The laws of proportioning concrete. Trans Am Soc Civ Eng (1907) 59(2): 67-143.

[10] M. Collepardi, The new concrete. Grafiche Tintoretto, Second Edition, Italy, 2010. 
[11] A. Baricevic, M. Jelcic Rukavina, M. Pezer., N. Stirmer, Influence of recycled tire polymer fibers on concrete properties. Cem Concr Compos (2018) 91: 29-41. https://doi.org/10.1016/j.cemconcomp.2018.04.009

[12] M. Pezer, M. Pavunc Samarzija, A. Baricevic, E. Vujasinovic, M. Jelcic Rukavina, N. Stirmer, Textile Fibres from Recycled Tyres, In: Z. Dragcevic, A. Hursa Sajatovic, E. Vujasinovic, (Eds.), Magic World of Textiles 2016, Dubrovnik, Croatia, University of Zagreb, Faculty of Textile Technology, Zagreb, 2016, 474-479.

[13] R. Čunko, M. Andrassy, Fibres, Zrinski d.d., Zagreb, 2005.

[14] P. Billberg, CBI Mix Design Model for Self-Compacting concrete, PhD course - Rheology of Cementitious Materials - Self-Compacting Concrete, DTU - Technical University of Denmark, Lingby, 2002.

[15] EN 12350-6:2009. Testing fresh concrete-Part 6: Density, European Committee for Standardization, 2009.

[16] EN 12350-7:2009. Testing fresh concrete-Part 7: Air content-Pressure methods, European Committee for Standardization, 2009.

[17] EN 12350-8:2010. Testing fresh concrete - Part 8: Self-compacting concrete-Slump-flow test, European Committee for Standardization, 2010.

[18] EN 12350-10:2010. Testing fresh concrete - Part 10: Self compacting concrete - L-box test, European Committee for Standardization, 2010.

[19] EN 12350-11:2010. Testing fresh concrete - Part 11: Self compacting concrete - Sieve segregation test, European Committee for Standardization, 2010.

[20] EN 12390-3:2009/AC:2011. Testing hardened concrete -- Part 3: Compressive strength of test specimens, European Committee for Standardization, 2011.

[21] EN 206-9:2010. Concrete -- Part 9: Additional Rules for Selfcompacting Concrete (SCC), European Committee for Standardization, 2010.

[22] The European Guidelines for Self-Compacting Concrete, Specification, Production and Use (2005), https://www.theconcreteinitiative.eu/images/ECP_Documents/Eur opeanGuidelinesSelfCompactingConcrete.pdf, last accessed 2020/1/14

[23] Technical Committee on Autogenous Shrinkage of Concrete, E. Tazawa (Ed.), Japan Concrete Institute: Autogenous Shrinkage of Concrete - Proceedings of the International Workshop Organized by JCl (Japan Concrete Institute), Hiroshima, Japan, June 1998, Taylor \& Francis Group, London and New York, 1-63, 1998.

[24] I. Gabrijel, M. Jelcic Rukavina, D. Bjegovic, Autogenous deformations of dolomite based self-compacting concretes with different mineral, in: D. Bjegovic, H. Beushausen, M. Serdar (Eds.), Proceedings of the RILEM International Workshop on Performance-Based Specification and Control of Concrete Durability, RILEM Publications S.A.R.L., Zagreb, Croatia, 2014, 507-514.

[25] J. Kaufmann, F. Winnefeld, D. Hesselbarth, Effect of the addition of ultrafine cement and short fiber reinforcement on shrinkage, rheological and mechanical properties of Portland cement pastes, Cem Concr Compos (2004) 26(5): 541-549. https://doi.org/10.1016/S0958-9465(03)00070-2

[26] L. Wu, N. Farzadnia, C. Shi, Z. Zhang, H. Wang., Autogenous shrinkage of high performance concrete: A review, Constr Build Mater (2017) 149: 62-75. https://doi.org/10.1016/j.conbuildmat.2017.05.064

[27] M. Serdar, A. Baricevic, M. Jelcic Rukavina, M. Pezer, D. Bjegovic, N. Stirmer, Shrinkage Behaviour of Fibre Reinforced Concrete with Recycled Tyre Polymer Fibres. Int J Polym Sci (2005), 2015: 310641 https://doi.org/10.1155/2015/145918

[28] A. Baricevic, M. Pezer, M. Jelcic Rukavina, M. Serdar, N. Stirmer, Effect of polymer fibers recycled from waste tires on properties of wetsprayed concrete. Constr Build Mater (2018) 176: 135-144. https://doi.org/10.1016/j.conbuildmat.2018.04.229 